\title{
Supply chain integration in the product return process: A study of consumer electronics retailers
}

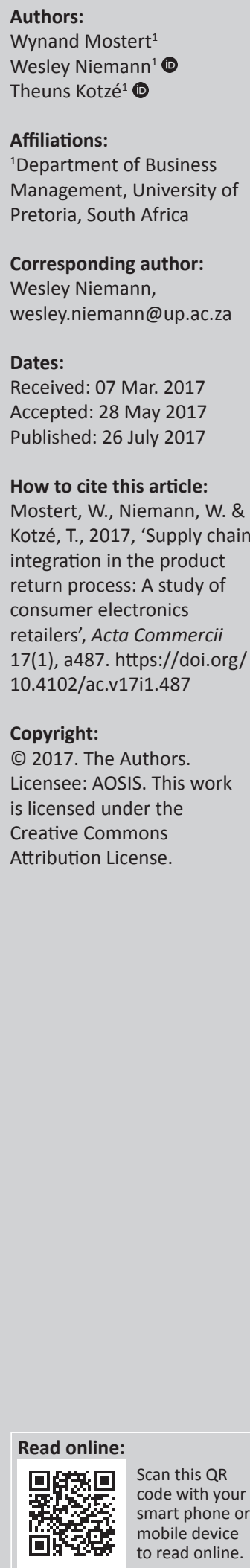

Background: The increasing complexity and levels of competition facing firms have reiterated the need to integrate the flow of goods and information within and between firms. Limited research has, however, been done regarding this integration in terms of reverse logistics.

Purpose: The purpose of this qualitative study was to explore the perspectives of retailers regarding supply chain integration in the context of product returns for consumer electronics.

Method: A generic qualitative research strategy was used for this purpose. Ten semi-structured interviews were conducted with managerial staff involved with the product returns process at large retailers.

Findings: The main findings indicate that the retailers made efforts to increase internal integration relating to improving information availability, aligning cross functional processes and improving inter-firm relationships. External integration efforts attempted to improve the intra-firm flow of information, reduce the number products returned to suppliers, expedite the returns process in specific instances and align processes. A narrow supplier-orientated span of integration was identified in this context, with integration efforts mainly targeting the start of the returns process to reduce return volumes. The study identified benefits attributed to both internal and external integration and barriers to internal and external integration relating to transactional relationships and suppliers who are incapable of integration.

Contribution: Academically, this study expands the literature on supply chain integration in an unexplored context. For managers, this study identifies various reverse logistics integration barriers and details what practices and strategies improve the probability of successful integration efforts.

\section{Introduction}

Recent developments, such as subdued economic performance (IMF 2016; OECD 2015), and increasing levels of cost, competition and regulatory pressures, have all contributed to making the current business environment increasingly complex and volatile (Fynes, de Búrca \& Voss 2005:3303-3304; Stevens \& Johnson 2016:20). These developments have re-emphasised the imperative for firms to increase the synchronisation of supply chain (SC) activities and build close, cooperative relationships with SC partners (Alfalla-Luque, Medina-Lopez \& Dey 2013:800; Kim 2013:74; Van der Vaart \& Van Donk 2008:52-53). The importance of reverse logistics (RL) has also increased because of trends that have led to increased product returns by customers (Janse, Schuur \& De Brito 2010:499). These include the increased importance of customer service levels, regulations such the South African Consumer Protection Act (68/2008), and shortening product life cycles (Bernon, Rossi \& Cullen 2011:485-486; Foscht et al. 2013:113-116; Powers \& Jack 2015:1182-1183).

Despite the importance of both supply chain integration (SCI) and reverse flows within the SC, there exists a gap in the literature regarding the role of SCI in RL, with recent calls from authors to expand on this area (Bernon et al. 2011:502-503, 2013:6 04; Flynn, Huo \& Zhao 2010:67).

Existing research on SCI is diverse, with three fields that have attracted the most attention. The first area of research regards the attempts made to form a definitive conceptualisation of SCI. Recent studies have described SCI along two main dimensions, namely internal and external integration, with external integration referring to integrating with both customers and suppliers (Flynn et al. 2010:58-61; Kamal \& Irani 2014:525-526; Stevens \& Johnson 2016:20-24; Williams et al. 2013:543-554). The second relates to the effects of SCI on both firm and SC performance. The literature on this topic is contradictory, because of diverse results regarding the impact of SCI on both firm and SC performance (Alfalla-Luque et al. 2013:800-801; Huang, Yen \& Liu 2014:64-65; 
Kim 2013:74-75). The third concerns the efforts and barriers associated with SCI. Several studies have sought to explore practices and conditions that are associated with successful and unsuccessful SCI initiatives (Bernon et al. 2013:586-587; Ralston et al. 2015:47-49; Richey et al. 2009:828-831).

A topic within SCI that has recently started to gain attention relates to its role in efficient RL management (Stock, Boyer \& Harmon 2010:36). Authors such as Bernon et al. (2013:586588 ) argue that there is a lack of research that integrates the two fields. In an attempt to answer the call for further research on the subject, this study seeks to build on the work of Bernon et al. (2013:586-608) by focusing on SCI in a retail RL context. This study focuses on product returns within the consumer electronics (CE) industry.

Product returns represents an increasingly significant responsibility for retailers, because of factors such as increased levels of product returns and returns process complexity, and regulations regarding the proper disposal of the waste created by these returns (Jack, Powers \& Skinner 2010:241-242; Srivastava \& Srivastava 2006:528-529). There also exist negative ramifications associated with its mismanagement, such as increased costs, and reduced profits and customer service levels (Guide \& Van Wassenhove 2009:14-15; Tibben-Lembke \& Rogers 2002:271-274).

\section{Problem statement}

Despite the importance of RL and specifically product returns, these functions are often seen as necessary evils, and are typically inefficient (Badenhorst 2016:1-2). As SCI has been argued to improve the performance of $\mathrm{RL}$, and specifically product returns (Bernon \& Cullen 2007:43-44), SCI within the context of product returns has the potential to impart significant benefits to firms. The efficient management of product returns is especially important for the South African retail sector, and specifically the CE industry. This is firstly because of the contributions the retail industry represents to the economy, both in terms of economic activity and employment (Statistics South Africa 2013:2-5; WESGRO 2013). Secondly, CE possesses characteristics that make efficient product returns critical, such as high value, levels of demand and environmental impact (Srivastava \& Srivastava 2006:528-529). South African companies have also indicated a focus on the benefits that SCI in the context of RL has been argued to provide, such as increasing financial returns, reducing operational costs and creating competitive advantage (Barloworld Logistics 2013:9-15, 2014:11-20; KPMG 2014:12-13). Despite this, little emphasis has been placed on specifically improving RL (Badenhorst \& Nel 2012:73-74). Thus, SCI within this context has the potential to positively impact the performance and competitiveness of the retail industry, but has so far received insufficient managerial and academic attention.

The goal of this generic qualitative study was to explore the perspectives of retailers with regard to SCI in the context of product returns in the retail CE industry. In doing so, it answered the call for further research on the topic. Specifically, the study attempted to identify the SCI efforts present in this context. It also attempted to explore perspectives on the span of integration, perceived benefits and barriers present within this context.

The following research questions guided the study:

- What are the internal and external SCI efforts of retailers within the context of the $\mathrm{CE}$ retail product returns process?

- What is the span of SCI present within the context of the $\mathrm{CE}$ retail product returns process?

- What are benefits of internal and external SCI within the context of the CE retail product returns process?

- What are the barriers to internal and external SCI within the context of the $\mathrm{CE}$ retail product returns process?

\section{Contribution to field}

Firstly, the study expanded on the existing SCI literature by examining SCI from the perspective of retailers in an unexplored context, namely within the product returns function of the South African CE industry. Secondly, it examined perceptions on the benefits that the combination of SCI and product returns activities provides, thereby adding to the existing literature regarding the links between SCI and firm performance. Finally, practical findings regarding the enabling practices and barriers to SCI were provided to managers, in order to improve their SCI efforts and overcome barriers to successful SCI, especially within the context of a developing country.

The structure of this article is as follows: firstly, a literature review covering pertinent concepts relating to SCI, RL and the link between the two concepts within the context of the CE industry is presented. Secondly, the research strategy and methods utilised in this study are described. Thirdly, the findings of the study are presented and discussed. Finally, the resulting implications for theory and management practices are discussed, and the study's limitations and suggestions for future research are presented.

\section{Literature review Supply chain integration}

SCI is a broad and complex term, and it is useful at this point to unpack the concept.

\section{Conceptualisation of supply chain integration}

SCI is a concept that focuses on achieving the improved synchronisation of processes and the enhanced exchange of high quality information throughout the SC, in order to improve both SC and operational performance (Huang et al. 2014:64-65; Narasimhan, Swink \& Viswanathan 2010:356-357; Prajogo \& Olhager 2012:515-516). SCI is often posited as consisting of both internal and external integration dimensions (Swink, Narasimhan \& Wang 2007:148-164; Wong, Boon-itt \& Wong 2011:604-615; Zhao et al. 2011:17-32). 
Internal integration refers to efforts within the focal firm to overcome functional boundaries and improve the level of cooperation and process alignment within the firm. In achieving this, the internal SC attempts to drive the pursuit of firm-wide goals instead of local, functional goals (Chang et al. 2015:2; Kamal \& Irani 2014:526; Richey et al. 2010:239-240). This is typically accomplished by implementing practices and processes which can be coordinated in a way that adds value to customers (Flynn et al. 2010:59). External integration refers to efforts to collaborate, share information and align processes with external SC partners (Flynn et al. 2010:59; Schoenherr \& Swink 2012:100-101). External integration is frequently divided up into customer and supplier integration, with each of these attempting to increase the amount of high quality information that is shared between SC partners, and their level of process alignment (Bakker, Boehme \& Van Donk 2012:1-3; Pagell 2004:459-462; Stevens \& Johnson 2016:30).

\section{Span of supply chain integration}

There exists a significant amount of literature regarding how the extent and breadth of SCI can be measured and characterised, with no consensus existing regarding the optimal system to use for this purpose (Flynn et al. 2010:61-62). Some systems, such as those created by Koufteros, Edwin Cheng and Lai (2007:847-870) and Narasimhan and Kim (2002:303-323), seek to measure and describe individual aspects of SCI, such as supplier or internal SCI. Others attempt to measure and describe SCI as a whole, concurrently measuring internal and external SCI (Schoenherr \& Swink 2012:99-115).

In their seminal work, Frohlich and Westbrook (2001:185:200) created a widely employed framework for measuring and describing the extent and direction of a firm's SCI efforts, based on the span of its SCI. This framework categorises firms based on how narrow or broad its span of integration is. A firm with a narrow span of integration will prefer to exclusively involve itself and its first-tier SC partners in its SC management and SCI efforts (Kannan \& Tan 2010:208-209). Conversely, a firm with a broad span of integration will prefer to involve SC partners beyond those it is adjacent to (Kannan \& Tan 2010:208-209). Using this scale, firms are categorised as being either inward facing, peripheral facing, supplier facing or outward facing, as illustrated in Figure 1.

Results from multiple authors who have used this system indicate that most firms have a narrow scope of integration and that firms with broad scopes are rare (Childerhouse \& Towill 2011:7455-7456; Frohlich \& Westbrook 2001:191-192; Kannan \& Tan 2010:213; Schoenherr \& Swink 2012:106107). In addition, firms typically first pursue internal SCI before attempting to integrate with external SC partners (Childerhouse \& Towill 2011:7443-7444).

\section{Benefits of supply chain integration}

The idea that SCI can have beneficial effects for the performance of firms and SCs has been argued since the inception of the concept. However, there is no clear consensus



Source: Childerhouse and Towill (2011:7442)

FIGURE 1: The arcs and span of integration.

on this subject in the literature resulting in calls for researchers to further investigate SCI's impact on performance outcomes (Afshan 2013:326; Autry, Rose \& Bell 2014:274-276).

The performance improvements associated with SCI are commonly divided into business and operational performance improvements (Mackelprang et al. 2014:72-73). In terms of improving operational performance, it has been suggested that SCI improves the efficiency and flexibility of logistics processes, the quality of outputs, and the visibility and quality of information throughout the firm (Mackelprang et al. 2014:72-73). SCI has also been argued to improve customer service levels, eliminate redundancies and reduce operational costs (Koufteros, Rawski \& Rupak 2010:74-80; Schoenherr \& Swink 2012:113-115; Vickery et al. 2003:537539). In terms of business performance, the operational benefits that SCI imparts allow for lower running costs relative to competitors, imbuing the firm with superior financial performance with regard to profit margins and return on investment (Chang et al. 2015:2-3).

\section{Barriers and enablers of supply chain integration}

Although SCI is an attractive goal for firms and SC practitioners alike, the reality is that the successful implementation thereof is a challenging proposition. Consequently, firms have struggled to successfully implement SCI initiatives, despite their desire and attempts to do so (Bagchi \& Skjoett-Larsen 2003:103-104; Dey \& Cheffi 2013:653-654; Richey et al. 2010:237-238).

\section{Barriers to supply chain integration}

Various authors have attempted to identify the factors that impede SCI, both in an internal and external context 
(Bakker et al. 2012:2; Richey et al. 2009:829-830). At this point, it is useful to review some of the most prominent barriers identified in the literature.

Barriers to external supply chain integration: The implementation of SCI is typically a resource-intensive process, requiring investments in process re-engineering and technological capabilities. This represents a major barrier to successful SCI initiatives, as firms may simply lack the resources and capabilities to successfully integrate with their SC partners (Huang et al. 2014:66-67). This is especially true in terms of information and communication technology (ICT) and the processes needed to facilitate information exchange (Prajogo \& Olhager 2012:519-520). Khurana, Mishra and Singh (2011:9-14) provide five distinct categories of factors that impede effective information sharing between SC partners. These include a lack of support by top management, the culture of the firms involved, and financial and technological limitations. These issues illustrate that lack of trust between SC partners often impedes external integration. Gil-Garcia, Chengalur-Smith and Duchessi (2007:123-124) found that sharing information becomes more complex as this sharing moves beyond the firm and occurs between SCs, while Fawcett, Magnan and McCarter (2008:94-98) found that inadequate information sharing and collaboration impede external SCI.

Barriers to internal supply chain integration: Ellinger, Keller and Hansen (2006:23-27) state that a lack of cooperation and alignment between business functions, and an absence of top managerial support stifle internal collaboration. This is a common position in the literature, with authors such as Richey et al. (2009:829-831) stating that inadequate internal integration management and functional silos in businesses are barriers to internal SCI. Furthermore, some functions often have disparate goals, definitions and measures of success and an innate resistance to change (Richey et al. 2009:829-831). Bakker et al. (2012:2-5) add that another major hindrance to internal SCI is firms that focus on addressing operational rather than strategic issues.

Georgise, Thoben and Seifert (2014:13) found that an absence of awareness of the potential benefits of SCI serves to impede SCI alongside operational inefficiencies. Heyns and Luke (2012:10-18) similarly found that a lack of skills and abilities critical to effective SCM activities is a global phenomenon, but is particularly pronounced in South Africa. Khurana et al. (2011:13) expand this idea that individuals and their behaviour can impede internal SCI initiatives, especially in terms of information sharing and information technology (IT) systems. The complex SC environments firms face also hamper decision-making (Manuj \& Sahin 2011:511-515). Storey, Emberson and Reade (2005:255-257) found that the complexities facing firms are underestimated in the literature, and that this greatly complicates identifying and understanding the internal barriers that are present.

\section{Enabling practices of supply chain integration}

A significant body of literature exists on how firms may overcome these barriers and successfully integrate, owing to the desirably of SCI and its potential benefits. The following section highlights various practices and factors that enable SCI between and within firms.

Enablers of external supply chain integration: Rai, Patnayakuni and Seth (2006:237-238) state that the use of IT is critical to achieve SCI between SC partners, serving as a platform through which the exchange of information can take place. This position of IT as a powerful enabler of SCI, especially through the enablement of information exchange, is supported by multiple studies (Li et al. 2009:134-138; Quesada et al. 2008:298-299; Stevens \& Johnson 2016:22-24). Li and Lin (2006:1642-1644) emphasise the importance of top management support and trust between SC partners in enabling the exchange of information that is critical to SCI.

There is support for the idea that improved levels of trust and power parity between SC partners can improve their willingness to take on the risks involved with SCI and the positive effects of the integrative initiatives undertaken. Sheu, Yen and Chae (2006:35-36) found several factors that significantly influence the relationship between SC partners, and ultimately concluded that high levels of relational intensity and interdependence in relationships are vital to effective integration.

Fugate, Sahin and Mentzer (2006:134) found that contracts between SC partners can enhance process alignment by ensuring that each partner pursues the same goal instead of seeking to maximise their own firm's benefits. Powers and Jack (2015:240-243) similarly found that contracts can improve performance in relationships between SC partners.

Bernon et al. (2011:497) state that integrating with the end customers in a retail setting is an overlooked but important element of SCI in this context. Customer integration here relates primarily to sharing information with customers, either via staff or centralised contact points. Bernon et al. argue that by ensuring that staff are trained to assist customers in buying the correct products and informing them on the products' proper use product returns volumes can be reduced. Bernon et al. (2013:600-603) similarly argue that training staff to assist customers and providing centralised contact points for customers enables customer integration.

Enablers of internal supply chain integration: Factors such as top management support, effective communication and cooperation through activities such as planning between functions and the alignment between functional goals all enable internal SCI (Pagell 2004:477-479). A formalised central internal structure has also been found to facilitate internal SCI (Richey et al. 2010:239-241). An information system has also been found to be a major enabler of internal integration, enabling cross functional information sharing and process alignment (Adaileh \& Abu-alganam 2010:277278; Mai, Chen \& Anselmi 2012:49). 
Fawcett and Magnan (2002:355-357) highlight the importance of centrally created standard procedures and policies in a retail context, stating that they can enhance relationships with first-tier SC partners. This also improves process transparency and enables firms to overcome the barriers prohibiting the integration of critical value adding activities. The concept that standard policies are conductive to internal integration is supported in the literature. For instance, Flynn, Koufteros and $\mathrm{Lu}$ (2016:21-23) found that a formalised strategy that is effectively communicated and understood is congruous with both internal and external SCI. Bernon et al. (2013:600-603) also found that readily available information on returns procedures increased process adherence, and, resultantly, the quality of information transmitted both internally and to suppliers.

\section{Reverse logistics and supply chain integration}

There are many definitions for RL. Some of the most prominent definitions are listed in Table 1.

This study adopts the definition of RL used by Rajagopal, Kaliani Sundram and Naidu (2015), because of its comprehensive description of the various flows and goals present in RL:

a systematic process that manages the flow of products, parts and information from the point of consumption to the point of origin, or the purpose of recapturing value or proper disposal. (pp. 39-40)

Although the above discussion showcases the extensive research that covers various aspects of SCI, Bernon et al. (2011:485-486, 2013:586-587) argue that research regarding SCI has hitherto focused on forward SC flows, with limited attention being paid to SCI within the context of RL. The forward flows through the SC have traditionally received far more academic and managerial attention than the reverse flows (Genchev, Richey \& Gabler 2011:242). RL activities have historically been characterised by elevated cost levels, extensive information asymmetries and a lack of alignment in terms of goals and incentives (Guide \& Van Wassenhove 2009:14-15; Stock \& Mulki 2009:33-34). It has, for instance, been found that the cost of processing a return can be up to $300 \%$ more than its value, highlighting the inefficient nature of returns activities and the resultant negative implications (Olorunniwo \& Li 2010:2-3).

\section{Importance of supply chain integration in a reverse logistics context}

Despite the dearth of literature directly linking SCI with improvements in RL, it is argued that SCI has the potential to have a positive impact in this context by addressing issues associated with RL, and consequently improving the efficiency with which it is managed (Bernon et al. 2011:495497, 2013:587-588). This concept has support within the literature, as demonstrated by the following discussion regarding how SCI can potentially address issues that are critical to RL.

Access to information: The availability of relevant, up to date information regarding the reverse flow of goods in the SC is critical to the effective management of RL (Huscroft et al. 2013:320-321; Mai et al. 2012:49). Conversely, the lack of returns information and subsequent process visibility has been identified as a major barrier to effective RL management (Srivastava 2013:65). The ability of both internal and external SCI to improve the availability of high quality process information has been widely argued within the literature (Kamal \& Irani 2014:541-542; Ralston et al. 2015:51-52; Richey et al. 2010:245), showcasing the potential benefits of SCI within this context.

Cost efficiency: Cost efficiency is widely seen as critical in relation to RL, owing to the typically low levels of operational and cost efficiency associated with the function, as well as its ability to positively impact the overall cost structure of a firm (Jack et al. 2010:228-229; Olariu 2014:190-191; Rajagopal et al. 2015:39-40). By improving operational performance while simultaneously reducing costs, SCI can improve the cost efficiency of processes and functions (Leuschner, Rogers \& Charvet 2013:292-293; Quesada et al. 2008:301-303; Richey et al. 2010:247-248; Rosenzweig, Roth \& Dean 2003:450-451). These operational performance improvements attributed to $\mathrm{SCI}$ include reduced cycle times, improved process alignment and lower costs and risks associates with logistics (Chang et al. 2015:2-3; Prajogo \& Olhager 2012). The cost efficiency of RL can thus potentially be improved through the successful implementation of SCI initiatives.

TABLE 1: Widely cited conceptualisations of reverse logistics.

\begin{tabular}{|c|c|c|}
\hline Source & Definition & Key characteristics \\
\hline Fleischmann et al. (1997) & $\begin{array}{l}\text { 'Reverse Logistics is a process which encompasses the logistics } \\
\text { activities all the way from used products no longer required by } \\
\text { the user to products again usable in a market'. }\end{array}$ & $\begin{array}{l}\text { - The focus is on the re-capturing of product value. } \\
\text { States that RL encompasses all logistics activities from point of } \\
\text { consumption. } \\
\text { States that the objective of RL is to capture value from returned } \\
\text { products. }\end{array}$ \\
\hline Rogers and Tibben-Lembke (1999) & $\begin{array}{l}\text { 'RL is the process of planning, implementing, and controlling } \\
\text { the efficient, cost-effective flow of raw materials, in process } \\
\text { inventory, finished goods and related information from the } \\
\text { point of consumption to the point of origin for the purpose } \\
\text { of recapturing value or proper disposal'. }\end{array}$ & $\begin{array}{l}\text { - The focus is on the efficiency of logistics activities. } \\
\text { - States that RL encompasses all backwards flows of materials and } \\
\text { information. } \\
\text { - States that the objective of RL is recapturing value or the disposal } \\
\text { of goods. }\end{array}$ \\
\hline The Reverse Logistics Association (2009) & $\begin{array}{l}\text { 'All activity associated with a product/service after the point } \\
\text { of sale, the ultimate goal to optimise or make more } \\
\text { efficient aftermarket activity, thus saving money and } \\
\text { environmental resources'. }\end{array}$ & $\begin{array}{l}\text { - The focus is on efficiency of aftermarket activities. } \\
\text { - States that RL encompasses all activities after a product has been } \\
\text { sold. } \\
\text { - States that the objective of RL is reducing costs and negative } \\
\text { environmental impacts. }\end{array}$ \\
\hline $\begin{array}{l}\text { Council of Supply Chain Management } \\
\text { Professionals (2013) }\end{array}$ & $\begin{array}{l}\text { 'A specialised segment of logistics focusing on the movement } \\
\text { and management of products and resources after the sale } \\
\text { and after delivery to the customer. Includes product returns } \\
\text { for repair and/or credit'. }\end{array}$ & $\begin{array}{l}\text { The focus is on the management of aftermarket activities. } \\
\text { - States that RL encompasses the management and movement of } \\
\text { goods and resources. } \\
\text { - States that the objective of RL is effective management. }\end{array}$ \\
\hline
\end{tabular}


Collaboration and coordination: The successful management of RL requires high levels of collaboration and coordination, both between internal functions and SC partners (Aitken \& Harrison 2013:759; Huscroft et al. 2013:320-321; Prakash \& Barua 2015:4). This is especially true in terms of the logistics processes involved in moving products backwards between different sites and SC partners (Jayaraman, Ross \& Agarwal 2008:410-412; Olorunniwo \& Li 2010:455-456). SCI by its very definition attempts to increase the levels of collaboration and coordination present between inter-firm departments and SC partners, and in doing so improves performance in terms of processes, firms and the overall SC (Chang et al. 2015:2; Huang et al. 2014:66-67; Jin, Fawcett \& Fawcett 2013:209-210; Kamal \& Irani 2014:535-537). Consequently, SCI has the potential to improve the functioning of RL by improving the levels of collaboration and coordination present between functions and SC partners.

\section{The consumer electronics industry}

$\mathrm{CE}$ is defined as 'equipment which is dependent on electric currents or electromagnetic fields in order to work properly and equipment for the generation, transfer and measurement of such currents and fields' (EPA 2016). Various factors make product returns critically important in terms of CE and the waste products generated by them being returned (PérezBelis, Bovea \& Ibáñez-Forés 2015:3-4). These factors include the increasing use of $\mathrm{CE}$ and the resultant increase in returned products and waste, the high value and environmental impact of CE, and the short product life cycle CE typically possess (Janse et al. 2010:495-496; Srivastava \& Srivastava 2006:524-527).

The South African CE industry is the continent's largest and has shown persistent growth in recent years (PWC 2012:28; WESGRO 2013:4-5). It is among the top 20 CE markets in the world and has recently been a significant source of foreign direct investment (PWC 2012:28; WESGRO 2013:4-5). Gauteng

\begin{tabular}{lllll}
\multicolumn{4}{l}{ TABLE 2: Details of participants. } \\
\hline Pseudonym & Job title & Gender & Organisation & Duration of interview \\
\hline P1 & Owner or executive & Female & O1 & $45 \mathrm{~min}$ \\
P2 & Returns manager & Male & O1 & $39 \mathrm{~min}$ \\
P3 & Brand director & Male & O2 & $44 \mathrm{~min}$ \\
P4 & Operations manager & Male & O3 & $42 \mathrm{~min}$ \\
P5 & Senior buyer & Female & O4 & $42 \mathrm{~min}$ \\
P6 & Operations director & Female & O5 & $53 \mathrm{~min}$ \\
P7 & $\begin{array}{l}\text { Regional operations } \\
\text { manager }\end{array}$ & Male & O6 & $38 \mathrm{~min}$ \\
P8 & $\begin{array}{l}\text { Senior operations } \\
\text { manager }\end{array}$ & Male & O7 & $52 \mathrm{~min}$ \\
P9 & $\begin{array}{l}\text { DC optimisation } \\
\text { manager }\end{array}$ & Male & O8 & $45 \mathrm{~min}$ \\
P10 & Returns manager & Male & O9 & $46 \mathrm{~min}$ \\
\hline
\end{tabular}

contains the highest population density and retail activity in the country, with the retail sector contributing $33.8 \%$ of the gross domestic product, and representing $35.4 \%$ of the country's total wholesale and retail and motor trade, and catering and accommodation activities (Statistics South Africa 2014:10-13). These characteristics illustrate that SCI has the potential to make a significant impact on the provincial and national economy by improving the performance of the $\mathrm{CE}$ industry in Gauteng.

\section{Retail reverse logistics and the product returns process}

Retail RL, within which the process of product returns falls, is a specific subset of RL (Olariu 2014:189). Retail RL is conceptualised similarly to RL, but with a focus on moving retail goods, and accompanying information, backwards through retail SCs (Olariu 2014:189-190). In replicating the work of Bernon et al. (2013:586-608), this study examines SCI in a retail RL context, specifically examining product returns. Product returns here encompass the return of products by customers because of a product defect or the customer's regret over the purchase (Rogers et al. 2002:3-4; Rogers \& Tibben-Lembke 1999:1-2). The importance of product returns has dramatically increased in recent years, mainly because of pressures in the forms of increased regulation, customer expectations and levels of competition (Srivastava \& Srivastava 2006:524-525). The effective management of product returns is critical to effective cost containment efforts, as extended periods in the reverse SC negatively affect profitability (Stock \& Mulki 2009:490-491). Delays within specific parts of the product returns process can also impede the success and resultant benefits of the process as a whole (Wee Kwan Tan \& Kumar 2006:346-348).

Numerous conceptualisations of the product returns process have been proposed by authors such as Bernon et al. (2011:490-492), Srivastava and Srivastava (2006:527-530) and Tibben-Lembke and Rogers (2002:272-274). Although there are differences in naming, these all posit a process made up of the phases illustrated in Figure 2.

This process starts with the customer requesting that the product be returned. This can occur telephonically, online or in the store where the product was purchased (Bernon et al. 2011:490). The second phase entails the retailer determining if it is a legitimate return, usually by inspecting the product for aspects such as warranty conditions, completeness and possible customer abuse (Bernon et al. 2011:490; Srivastava \& Srivastava 2006:528). In a retail context, this step is often accompanied by the capturing of customer and product details onto a centralised system (Tibben-Lembke \& Rogers 2002:272). If it is deemed to be a legitimate return, the product

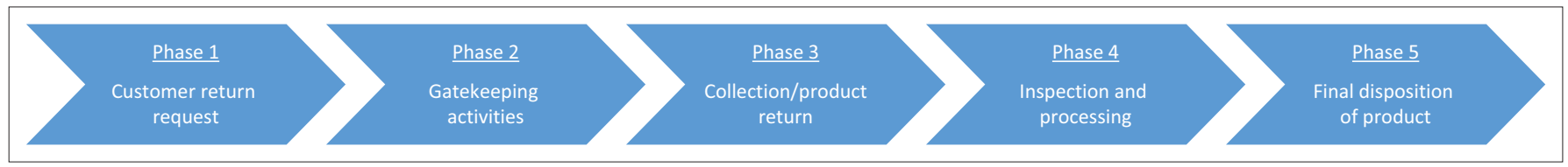

Source: Bernon et al. (2011:490-492); Srivastava and Srivastava (2006:527-530); Tibben-Lembke and Rogers (2002:272-274).

FIGURE 2: The product returns process. 
is then returned to the supplier or to a repair agent, either via direct collection from the customer or via the retailer (Bernon et al. 2011:491; Tibben-Lembke \& Rogers 2002:272). Once the product has arrived at the specified facility, a thorough inspection regarding the product's condition is made, and it is categorised accordingly (Bernon et al. 2011:490-491; Srivastava \& Srivastava 2006:528). Finally, the product is sent to the appropriate disposal activity, such as remanufacturing, recycling, disposal or reselling (Bernon et al. 2011:490-491; Tibben-Lembke \& Rogers 2002:272-273). Bernon et al. (2011:491-492) argue that this phase represents an area where major improvements can be made through SCI initiatives, for example by speeding up the authorisation of returns received, ensuring that high quality information is captured and disseminated to all relevant parties and employing effective gatekeeping.

\section{Methodology \\ Research design}

The study employed a generic qualitative research design. Generic qualitative research is used to investigate individual perspectives regarding either their own experiences or external events (Plano Clark \& Creswell 2015:289). Percy, Kostere and Kostere (2015:76-78) states a valid approach to qualitative research where the purpose is to explore various perspectives surrounding a specified topic to create a detailed understanding of how the different participants experience it. This study attempted to create a deeper comprehension of how retailers experience SCI in the context of CE product returns, making a generic qualitative design the most appropriate.

\section{Sampling}

The unit of analysis for this study was the internal and external integration efforts of retailers in terms of product returns. This study used homogenous sampling in order to identify the firms that were selected. Plano Clark and Creswell (2015:334) state that homogenous sampling occurs when the researcher samples site because they belong to a specified subgroup, defined by specific characteristics. Homogenous sampling was appropriate for this study because it sought to learn about the perspective of a specific type of firm, namely large retailers who sell CE. Online searches were used to identify potential participating firms that possessed the following inclusion criteria: CE was one of their main product categories, they were classified as large firms according to the National Small Enterprise Act (102/2003), and they had a regional head office and multiple stores in Gauteng.

Homogenous sampling was also used to select the individual participants who participated in the study. As this study sought to learn more about a specialised topic, it was crucial that all theindividual participants shared certain characteristics and were able to provide high quality, relevant information (Plano Clark \& Creswell 2015:334). The selected participants shared the following characteristics: they were middle or senior managers in their firms, were directly involved in the product returns function and were knowledgeable about the RL functions of their firms. Individual participants were identified through telephonic and email correspondence with qualifying firms.

The principle of data saturation was used to ensure an adequate sample size was selected for this study, in order to overcome the difficulties qualitative researchers often experience in deciding upon a sufficient sample (Francis et al. 2010:1230; Plano Clark \& Creswell 2015:336). Data saturation is reached when the new data and insights gained by conducting additional interviews is found to be marginal and insignificant (Bowen 2008:140). Francis et al. (2010:1234) argue that at least 10 interviews should be completed, and that data saturation occurs once three consecutive interviews are completed without new information arising.

\section{Data collection}

This study used face-to-face semi-structured interviews for data collection. This form of data collection was appropriate as it allowed the researcher to comprehend and detail the complex phenomenon being studied, namely how these senior managers perceive SCI within the context of product returns (Creswell 2012:214; Saunders, Lewis \& Thornhill 2016:168). A discussion guide was developed after the completion of a thorough review of the existing literature and discussions with an experienced SC academic. A pilot study was conducted with an executive at a CE retailer. The outcome was positive and the discussion guide was used without major alterations. Ten face-to-face semi-structured interviews were conducted over a period of two months. The interviews lasted $45 \mathrm{~min}$ on average. The researcher transcribed the interview recordings and stored the original recordings and transcriptions in a secure, online repository to ensure their safety.

\section{Data analysis}

Thematic analysis was done on the collected data. This method of data analysis is employed to recognise, categorise and comprehend themes that emerge from the collected set of data (Braun \& Clarke 2012:57). The researcher first familiarised himself with the data by carefully analysing both the audio recording and the respective transcription. Codes were then generated and combined with priori codes generated from the literature to create a master list of codes. The codes were matched to relevant areas of text within the transcriptions. Similar or redundant codes were then combined or deleted as needed. These refined codes were then analysed and combined into a set of descriptive, overarching themes. These themes were then analysed against the original transcriptions to ensure that they covered all present patterns. The process was repeated where required.

\section{Trustworthiness}

Multiple techniques were employed to ensure the credibility, transferability, dependability, conformability and authenticity 
of the study, and in doing so ensure overall trustworthiness (Polit \& Beck 2012:585; Shenton 2004:64). Credibility was ensured by employing site triangulation, which entails making use of participants from multiple firms to ensure that the identified themes are not unique to a specific firm (Shenton 2004:66). Secondly, to satisfy the criteria of transferability and authenticity, a thick, descriptive background to the research was created. To this end, the discussion guide and a coherent explanation of the data analysis process followed were included. Comprehensive descriptions of the firms and individual participants were also included (Creswell 2007:209; Polit \& Beck 2012:585). Thirdly, to ensure confirmability, triangulation was employed to establish a clear link was between the collected data and the reviewed literature. Finally, dependability was ensured by creating comprehensive descriptions of the research design, the manner of its implementation and the nature of the data collection (Thomas \& Magilvy 2011:153).

\section{Ethical consideration}

This study was given ethical clearance by a research ethics committee at a South African university. All participants were provided with an informed consent form before the interview started, which they were required to read and sign. The form stipulated that participation was voluntary, that a participant could withdraw at any time, and ensured the confidentiality of the responses and the anonymity of the participant. In order to ensure the confidentiality of participants, every reference to the identity of the participants or their firms was removed from the transcriptions (2016/08_ Mostert).

\section{Findings}

This study identified four main themes, as indicated in Figure 3. These themes relate to the following: the integration efforts undertaken by the participating firms, the span of integration identified in terms of the product returns process, the benefits attributed to SCI and the barriers related to SCI. These themes are discussed in this section, accompanied by descriptive quotations from participants and linkages to the relevant literature. These findings are also compared and contrasted with those of Bernon et al. (2013:596-601) to establish if they confirm or contradict them.

\section{Internal supply chain integration efforts}

Internal SCI efforts refer to the strategies and enabling practices with which firms attempt to improve the alignment of their internal processes and functions (Basnet 2013:153155). These efforts are often categorised as either information sharing activities, cross functional processes or relational integration (Schoenherr \& Swink 2012:100-101).

\section{Information sharing}

The effective sharing of quality information across departments is critical to internal SCI, as it improves decisionmaking and process efficiency, especially in an RL context (Mai et al. 2012:49; Prajogo \& Olhager 2012:514-516). All of the participants indicated that the use of a central information system aids them in capturing and disseminating returns information to relevant departments. The following quote illustrates the type of system identified:

\begin{abstract}
'So, if something comes in we will take it through our CRM system, and on the CRM we have something called a case, so we will open our cases and each case will ... This line has a power supply issue, this one has a motherboard issue this one ... So each one then comes with a different issue then. And the reporting around that will then say $X$ percent failed because of this and X-percentage failed because of that.' (P8, male, senior operations manager - translated)
\end{abstract}

Six of the participants identified other mechanisms in place that facilitated enhanced information sharing between departments and subsequently improved their decisionmaking abilities in terms of the product returns process (Mai et al. 2012:49). These ranged from interdepartmental meetings to the use of technologies such as email and messaging applications. This is illustrated by the following quotes:

\begin{tabular}{|c|c|c|c|}
\hline $\begin{array}{l}\text { Theme } 1 \\
\text { sCl efforts }\end{array}$ & $\begin{array}{c}\text { Theme } 2 \\
\text { Span of SCI }\end{array}$ & $\begin{array}{c}\text { Theme } 3 \\
\text { Benefits of SCl }\end{array}$ & $\begin{array}{c}\text { Theme } 4 \\
\text { Barriers to SCI }\end{array}$ \\
\hline $\begin{array}{l}\text { - Internal SCI efforts } \\
\text { - Information sharing } \\
\text { - Cross functional } \\
\text { processes } \\
\text { - Relational integration } \\
\text { - External SCl efforts } \\
\text { - Supplier integration } \\
\text { - Improving information flow } \\
\text { - Process alignment } \\
\text { - Returns reduction } \\
\text { - Customer integration } \\
\text { - Training of staff } \\
\text { - Central point of } \\
\text { contact for customers }\end{array}$ & $\begin{array}{l}\text { - Overall span of integration } \\
\text { efforts identified } \\
\text { - Classification of firms } \\
\text { by span of } \mathrm{SCl} \\
\text { - Span of integration } \\
\text { efforts with regard to } \\
\text { specific product returns } \\
\text { process phases }\end{array}$ & $\begin{array}{l}\text { - Benefits of internal SCI } \\
\text { - Improvements in } \\
\text { operational performance } \\
\text { - Benefits of external SCI } \\
\text { - Improvements in } \\
\text { operational performance } \\
\text { - Improvements in } \\
\text { business performance }\end{array}$ & $\begin{array}{l}\text { - Barriers to internal SCI } \\
\text { - Process non-adherance } \\
\text { - Resistance to change } \\
\text { - Need for training and } \\
\text { change managment } \\
\text { - Internal complexity } \\
\text { - Barriers to external SCI } \\
\text { - Transactional } \\
\text { relatioships } \\
\text { - Suppliers lacking the } \\
\text { resources and capabilities } \\
\text { to integrate } \\
\text { - External complexity }\end{array}$ \\
\hline
\end{tabular}

FIGURE 3: Summary of themes. 
'We call it merge and regional monthly meeting. It is literally a gripe session, in a professional way of course. We make lists of specific issues beforehand that we as buyers and planners have with the shops. Things we feel are not followed up on or resolved, and the shops do the same.' (P5, female, senior buyer - translated)

'If it is something that one store has to ask another store quite quickly we do have WhatsApp groups in place. We have one group that is all our employees on, just one general group. Then we have a group of all of the manager: operations group, we've got a warehouse group.' (P10, male, returns manager)

These findings confirm those of Bernon et al. (2013:602-603), who identified the use of an integrated reporting system and weekly, cross functional meetings to improve intra-firm information sharing.

\section{Cross functional processes}

The synchronising of processes and goals across departments has been established within the literature as being integral to internal SCI (Flynn et al. 2010:60; Mai et al. 2012:48-49). All participants indicated efforts to implement this form of synchronisation. Seven participants suggested the use of centralised structures, systems and controls to ensure that processes and goals were aligned across departments and retail outlets. A centralised IT system was critical to the facilitation of this alignment, as described here:

'When you capture it, we capture all of the customer's details. You capture the customer's delivery address, you will scan their slip so that we can see if it is in warranty or out of warranty, and based on that the guys at head office who will decide how to book it.' (P7, Male, Regional operations manager)

'So we've got a central server with different drives assigned to different departments so there is a drive for sales and drive for the back office and for finance and for technical. So we treat this as a repository so there is a repository on the technical drive that records established warranty policies for each of the suppliers. So, that is available for all of the technical teams across the country.' (P3, male, brand director)

This finding is in line with previous studies (Bernon et al. 2013:597-599; Flynn et al. 2016:21-23) which identified the use of this form of a centralised system to improve internal SCI.

\section{Relational integration}

Close interdepartmental relationships, and the disposition of top management towards managing returns, play a central role in enabling internal integration (Mai et al. 2012:4748; Pagell 2004:477-479). Multiple forms of relational integration were identified. Four participants emphasised the improvement of amicable relationships between departments, three indicated the use of area managers to manage the relationship between head office and stores, while seven indicated that top management support was integral to implementing internal SCI initiatives. A participant illustrated the role of top management in coordinating information flows and processes:

'[In relation to implementing a companywide change] When I came into the business, I went through all the SLA's and saw that we don't have to do it that way. I didn't know why we were doing it that way, it was unnecessary cost. I basically called a meeting with the whole team, with all the store managers, and said this is how the process is now, according to the SLA this is how it is supposed to be. This is how much it costs us now, by implementing this it will cost us nothing, and we will cut out the extra transportation. So, I changed it.' (P8, male, senior operations manager - translated)

This finding confirms that of Bernon et al. (2013:602-603) in that the ability of top management to enact overarching SCI efforts and align functions improves internal SCI.

\section{External supply chain integration efforts}

External SCI relates to the extent to which a firm collaborates with its SC partners to align inter-firm processes and information flows. This dimension of SCI is routinely categorised as supplier or customer SCI (Flynn et al. 2010:59). The identified supplier SCI efforts relate to: the use of contracts to reduce return volumes and align objectives, improving the flow of information between firms through dedicated contact points and electronic information exchange, and the alignment of inter-firm processes. The identified customer SCI efforts relate to educating customers to reduce return volumes and the use of a centralised call centre. Detailed discussions of the identified external SCI efforts follow.

\section{Supplier integration}

Nine of the participants indicate that their organisation use contracts with suppliers as a form of SCI. These agreements served to either reduce the number of products sent back to suppliers from the retailers or to align the incentives of the SC partners and ensure efficient handling of responsibilities in terms of product returns. One participant described the incentive aligning nature of these contracts:

'So as soon as we see it has been logged, they have 14 working days. At the end of those 14 working days, if the unit has not appeared back in the store, it is not our problem, we go back to corporate and say this unit is 15 days old, please give me a credit. They will then get in touch with the supplier and say you have not repaired it in the SLA period, please pass credit.' (P7, male, regional operations manager)

This finding conforms to the integrative capability of contracts described by Fugate et al. (2006:134) insofar as the contract ensures that each party pursues a global optimum.

The provision of standardised processes, and training for store level staff in terms of these processes, is argued to improve process alignment in the retail context, while also lowering return volumes (Bernon et al. 2013:597-599; Stanley et al. 2002:355-357). This is because of these procedures improving information on the returns process at store level, while also improving employee adherence to these processes. Four participants indicated that suppliers provided training on the returns process. All participants indicated that suppliers provided standard operating procedures of the returns process, which were disseminated to their stores. This also improved customer service, as illustrated here: 
'For every product that there is, there is a place where we go on, if you book it back into your system as a repair, it immediately gives you the returns process for that product or brand ... because we want to differentiate ourselves from the other retailers.' (P5, female, senior buyer - translated)

The effective and mutual exchange of information between firms is critical to supplier integration and is often enabled through integrated information systems and direct contact (Prajogo \& Olhager 2012:514-516). The participants indicated numerous practices in place to improve this flow of information between firms, including dedicated contacts for product returns for suppliers and regular meetings. This enabled more efficient inter-firm communication, the ability to track and expedite specific returns, and the ability to have suppliers act on specific issues leading to increased returns:

'[Regarding whether a dedicated contact at a supplier improves the flow of information] It does, you can ask them questions. You can question why don't you want to take it back, what is wrong and what can we do.' (P2, male, returns manager)

'So, if there is a problem with a product, and the failure rate is higher than it should be, we then normally talk to the buyers, is this a problem and are you aware of it? Then we bring it to the supplier's attention. Then sometimes the whole product is recalled.' (P7, female, operations director - translated)

Four firms in this study exchanged returns data between their respective IT systems. This exchange of information was primarily achieved through the manual exchange of information extracted from the retailer's system, or from returns logged on an online portal. This exchange improved the efficiency of the product returns process, while also allowing simplified tracking of specific items. It was also limited to the retailers' largest suppliers with whom they also had the closest relationships. Two participants illustrated how this form of exchange occurred:

'It is mainly the Excel sheets. We export it in XML from FINCON, via a data folder. The other suppliers' repair centres [pause] Some of them have online systems like I have told you, but the online systems are not up to date, because it is still a person updating it.' (P7, female, operations director - translated)

'So most of our suppliers are integrated with one another. So, we sell to a customer and give an invoice and that invoice has a serial number if there is a serialised piece of inventory and when we return it we return it on that serial number and that goes through to the supplier electronically. So, there is no real paperwork involved.' (P4, male, operations director)

These findings support the enabling role of IT and close relationships in information exchange (Prajogo \& Olhager 2012:514-516), and also align with the views of Sheu et al. (2006:44-45), in that relationship intensity and interdependence are positively linked to the level of external SCI.

\section{Customer integration}

Customer integration refers to an increased alignment with customer needs by sharing information and collaborating with them (Schoenherr \& Swink 2012:100).
Three of the participating firms used a centralised call centre to aid customers with any issues they may experience with product returns. This ensured that customer issues were resolved as quickly and effectively as possible, while also ensuring that effective gatekeeping was enforced and problematic staff identified and addressed. The workings of this hotline are detailed in the following quote:

'He phones the helpline and it gets logged and it then gets assigned. When it gets assigned, it gets assigned back to the branch, and the branch must then get feedback on what the issue is, and the resolution. If we feel that the branch was at fault, we will make them contact the customer and resolve it.' (P7, male, regional operations manager)

Four participants indicated efforts to educate customers about product details and usage in an attempt to reduce returns by avoiding incorrect purchases and accidental product abuse. Two participants described their respective approaches as follows:

'In the third week of the month I bring all the domestic workers in the area and they come in and we show them how to use the products so that they don't break them.' (P1, female, owner/ executive)

'You will find quite often that when that type of product comes in, like I said we will do basic test when the customer brings the product in, and at that basic test points will find that it is working and you will tell the customer that what they were doing wrong, and then $9 / 10$ times the customer takes the products and go goes home with it.' (P7, male, regional operations manager)

These findings are in line with those of Bernon et al. (2013:597-599), who found that a centralised contact point for customers with product returns complaints or queries, combined with their education, helped reduce return volumes and improve customer service levels.

\section{Span of supply chain integration within the product returns process}

As illustrated in Figure 1 the span of SCI relates to the extent that a firm includes SC partners in managing SC processes, and can range from narrow, indicating minimal integration with peripheral SC partners to broad, indicating significant involvement of SC partners across multiple levels of the SC (Kannan \& Tan 2010:208-209).

Overall, the span of SCI in terms of the returns process was found to be narrow. Six participants indicated more internal than external SCI efforts within this context, while one indicated an even split. All the external integration efforts identified within this context were also focused on first-tier SC partners, with all participants indicating significantly more SCI efforts in relation to suppliers than to customers. Resultantly, all the participating firms can be classified as supplier facing in the context of the product returns process.

This narrow span is also evident when examining SCI efforts in terms of the specific phases of the product returns process. The majority of integration efforts undertaken by the participating firms targeted the first two phases of the process 
indicated in Figure 1, namely the customer return request and gatekeeping phases. These SCI efforts were aimed at ensuring that only legitimate returns were accepted at store level, and that high quality product and customer information was captured for dissemination throughout the firm. Participants frequently indicated minimal knowledge of their supplier's involvement in the process, and few of them knew what became of products once they left their firm. The following quote illustrates this attitude:

'I suppose it might be a factor that consumer products which, is mostly what we carry, there is an assumed failure rates which is relatively low and a lot of retailers treat failure as almost like exceptions and this is where you find that some of the other retailers especially, if they have a product that comes back from the customer, most of the time they just credit without asking any questions so they just treat that as an exception.' (P3, male, brand director)

The narrow span of integration identified is in line with the literature on the subject, as firms with narrow spans of integration are far more prevalent than those who have broad spans (Frohlich \& Westbrook 2001:191-192). These findings also confirm the findings of Bernon et al. (2011:495$498,2013: 597-601)$ that in the first two phases of the product returns process are especially susceptible to performance improvements by SCI initiatives and resultantly targeted. This is because of the fact that efforts directed at these phases can limit the number of returns that are accepted into the reverse flow, and ensure that high quality information is captured at the point of return. This is in line with literature regarding the importance of reducing product returns in the context of CE, as illustrated by the example of Philips Consumer Electronics focusing on achieving this goal (Sciarrotta 2003:32-38).

\section{Benefits of supply chain integration}

Firms pursue SCI for the beneficial effects, it is argued, it imparts on the performance of both firms and SCs (Afshan 2013:323-325). These benefits are widely categorised as improvements to either operational or business performance, as discussed previously. This study identified various benefits attributed to internal and external SCI, as illustrated in Figure 2 and detailed below.

\section{Benefits of internal supply chain integration}

The benefits attributed to internal SCI relate to improvements in both business and operational performance (Mackelprang et al. 2014:71-73). The benefits attributed to SCI most frequently indicated by participants related to improved operational performance. These benefits included the improved availability of high quality information, increased process adherence and a reduction in product return volumes received from customers.

Evidence exists that internal SCI can improve the availability of relevant, high quality information throughout a firm, and subsequently improve decision-making (Mai et al. 2012:49). Every participant identified this improved information quality and availability, enhancing process visibility and decision-making, as illustrated by the following quote:

'So that is then basically going to be visible to that directors and the area manager to sort that out and talk to the relevant people

... For instance, identify a fault, identify the faulty product that they will have to talk to the suppliers about.' (P10, male, returns manager)

Internal SCI has also been argued to increase process adherence and the alignment of processes across functions, especially though the use of standardised processed and centralised systems to monitor and enforce adherence (Bernon et al. 2013:600-603). Eight participants indicated improved adherence to returns processes as a benefit of internal SCI, while seven identified improved process alignment, as showcased by these quotes:

'We get a daily report, that gets sent out and gives you the details.
It will say the item has been booked in, it will tell you that it is
booked in but all the information is incomplete. So, you have a
view immediately, you can filter to see what hasn't been done
accurately, and then you get on to the stores. The managers check
that report every day to make sure that everything for the report
is compliant.' (P7, male, regional operations manager)
'Most of the time if you look at the suppliers that are manually
written up, that comes directly from the branches so the branches
and the service department do the write up for that specific unit.
So, before it comes to me the request for credit has already been
sent out so when it gets to me it may be a day or two before
the supplier comes to collect it. So, it makes it more efficient.'
(P2, male, returns manager)

Direct links between internal SCI, especially with regard to its ability to improve intra-firm information flows and customer service levels, have been identified within the literature (Vickery et al. 2003:537-539). Half of the participants attributed improved customer service levels to internal SCI, as one participant described with the following quote:

'[Regarding whether the improved information flow from their CRM system improves customer information] Yes most definitely. So, we use a CRM system that our web service talks to. In the CRM system, you can put in notes and those notes fly up and down between companies and back to customers. At all times, we still tend to mail the customer whatever the supplier told us is the issue and in certain instances we will SMS customers, if we have this numbers on the system. So, the CRM system will SMS them. So it speeds up the communication gap between customer ourselves and suppliers.' (P4, male, operations director)

These findings confirm and add to the benefits identified by Bernon et al. (2013:597-601), who found that internal SCI improved information accuracy, decision-making and the ability of top management to successfully implement overarching SCI initiatives. This study added to these findings by confirming improved levels of customer service and reduced levels of product returns received as additional benefits in this context, confirming the existing literature (Bernon \& Cullen 2007:54-55; Vickery et al. 2003:537-539). In addition, internal SCI's ability to increase process adherence was identified as a novel finding in this context. 


\section{Benefits of external supply chain integration}

SCI between SC partners has been argued to be beneficial to both the individual firms and SC as a whole (Mackelprang et al. 2014:71-73). The benefits attributed to external SCI can also be categorised as either operational or business performance improvements, and relate to improved information exchange between SC partners, and improved process alignment and efficiency (Mackelprang et al. 2014:72-73). Participants attributed benefits in both of these categories to external SCI, as discussed below.

In terms of operational performance improvements, participants indicated that external SCI improves process alignment, efficiency and information flow between SC partners. Customer service is also improved by the product returns process being expedited in certain cases. The perceptions surrounding these operational performance improvements are represented by the following quotes:

'The updates that we receive from the suppliers are then input into our FINCON program, via a customer repair order note. Any time when any of us want to go in and follow up for a client, we can then just go in on the system and see what is the last note or update on it.' (P7, female, operations director - translated)

'Because once that exchange has been done it obviously becomes your stock that needs to go back to the suppliers and if there are not collecting on time then you again just raise an escalation and in those weekly meetings they will talk to the suppliers, and start moving that stock out.' (P7, male, regional operations manager)

'Because if you already have a personal relationship with the guy you can say listen I've got this product I really needed sorted, the client is very agitated because he boarded a month ago and it is not working any more, can you please get this sorted? So, I believe that any form of direct contact with the supplier there is always a way of speeding up the process yes.' (P10, male, returns manager)

The ability of external SCI to impart these specific benefits is supported within the literature (Leuschner et al. 2013:38-40), and the findings of the study here confirm the existence of these benefits within its context.

In terms of business performance, the main benefit identified was cost savings because of reduced returns between retailers and their suppliers. SCI between SC partners can enable product returns to be processed and disposed of at retail level, avoiding the need for additional returns activities and increasing the relative value recovered from returned goods (Bernon \& Cullen 2007:54-55; Bernon et al. 2011:495-496). Eight participants indicated that agreements with suppliers allowed them to reduce the number of returned products they sent back to suppliers, as described by the following quote:

'Some suppliers actually give us an allowance to absorb the returns and the damages. They say so listen, if it is damaged dispose of it do anything you want to do with that let us... And it is actually an allowance that happens.' (P9, male, DC optimisation manager)

This finding partially contradicts that of Bernon et al. (2013:597-601). Although they found that external SCI can lead to reduced returns via the use of a call line for customers, they argue that contractual agreements between retailers and their suppliers increase the transactional nature of their relationship. This finding is, however, in line with those of others who advocate the ability of contracts to improve performance and assure alignment between the goals of individual SC partners (Powers \& Jack 2015:240-243; Fugate et al. 2006:134).

\section{Barriers to supply chain integration}

Numerous factors impede SCI, both within a firm and between SC partners (Prajogo \& Olhager 2012:519-521; Richey et al. 2009:829-831). Figure 2 illustrates the internal and external SCI barriers indicated by participants. A discussion of the major identified internal and external barriers follows.

\section{Barriers to internal supply chain integration}

Internal SCI barriers are those factors that inhibit the effective coordination and alignment of internal functions and flows (Bakker et al. 2012:1-2). The most commonly indicated barriers are process non-compliance, resistance to change and complexity in terms of internal systems and products, with each of these being indicated by at least four participants.

Individuals are often resistant to changing systems or processes, and change management and training is required to overcome this resistance (Richey et al. 2009:829-831). This resistance was indicated as an internal barrier, especially for integrated information systems:

'You have people that have been working for this company for 40 years. They have done things differently, they have dealt with certain people, so once you centralise something you want someone with the capability of doing that and is actually willing to come in and put to work in. So, you find that that person gets quite a bit of resistance.' (P9, male, DC optimisation manager)

Process non-compliance is different to resistance to change in that it relates to employee non-adherence to entrenched, standardised processes, resulting in low-quality information and process outputs (Bernon et al. 2013:606; Khurana et al. 2011:13). As shown below, this inefficiency counteracts the increased alignment that internal SCI pursues:

'We still have a challenge in that instructions that are given from headquarters to the shops are not implemented, or the correct processes aren't followed. Now am I am sitting with, silly example, 200 identical printers that need to be returned to [Supplier]. ... Now my planner followed up this week why they were not returned. There are about 105 of those printers which are damaged printers, printers which need to be repaired. The stores had never followed the process to send the printers back to the supplier for repairs.' (P5, female, senior buyer - translated)

These findings are in line with those of Bernon et al. (2013:601-603), who found that the resistance to change and process non-adherence found within retailers impede SCI efforts. 


\section{Barriers to external supply chain integration}

External barriers to SCI refer to those factors that inhibit effective coordination and information sharing between SC partners (Bakker et al. 2012:1-2). Commonly indicated external barriers relate to issues faced by many South African firms, namely suppliers lacking resources and capabilities, the complexity involved with external SCI and the transactional nature of retailer-supplier relationships.

SC partners are often unable to integrate with one another because of a lack of relevant resources and capabilities, such as capital, IT systems and management know-how (Huang et al. 2014:66-67). This barrier was indicated by six participants, and aligns with the lack of SCM skills and capabilities present within the country:

'So, there are other smaller suppliers that you cannot integrate with because they do not have the capability to do it.' (P4, male, operations director)

The complexity involved in aligning the different IT systems, processes and products possessed by SC partners can be a major barrier to integration and effective decision-making (Richey et al. 2010:240; Manuj \& Sahin 2011:511-515). In line with previous findings, the complexity involved with external integration was also identified as a barrier to SCI. This complexity impeded agreements with smaller suppliers as shown by this quote:

'It would take all day. We are going to be doing that every day, it is just not going to be practical at all.' (P9, male, DC optimisation manager)

Transactional relationships, here characterised by inadequate information sharing and subsequent collaboration (Fawcett et al. 2008:93-98), make external SCI less likely. This type of behaviour was indicated by four participants, and resulted in suppliers not exchanging information and adhering to service level agreements:

'We can't rely on when the supplier is going to think about the product, there can be a risk for us for us because the supplier can decide to end the life of the product and we have to say while we have 5000 of this particular product in the market and we need to have at least $5 \%$ spares holding to support the next one year of the warranty claims and sometimes the vendors as well say sorry we haven't catered for that.' (P3, male, brand director)

\section{Conclusion}

\section{Summary of findings and theoretical implications}

This study reported findings in the four areas it sought to address. Firstly, the study explored the specific efforts undertaken to increase both internal and external SCI in the product returns process. The four forms of integration identified by Bernon et al. (2013: 597-602), namely external process integration, the use of an internal integrated reporting system, the integration of information systems with suppliers and both internal and external process and relational integration, are all found to be present in the product returns process in the Gauteng retail CE industry. This serves to confirm their findings in this area. The study also expands on these findings by establishing the role of contracts and interdependent, intense relationships in improving SCI between SC partners in this context. Contracts between retailers and their suppliers are found to increase the alignment of objectives and processes across firms, and contribute to a more efficient product returns process by reducing the number of returned goods sent to suppliers. Intense, interdependent relationships are found to be a critical enabler of external SCI, as retailers are reluctant to integrate with suppliers with whom they have a transactional relationship.

Secondly, the study identified the span of SCI present in the context of the product returns process. It was found that the overall SCI within this context is narrow in scope, favouring internal SCI over external SCI. External SCI efforts exclusively involved first-tier SC partners and were significantly skewed towards suppliers. Resultantly, the participating firms were classified as supplier facing. In terms of the specific phases of the product returns process, the SCI efforts of the participating firms targeted the first two phases, namely the customer return request and gatekeeping phases. There was an emphasis on ensuring that only legitimate returns were accepted, and that the information regarding these were efficiently captured and disseminated. These findings also confirm the existing literature on the predominant span of integration, and narrow spans of integration are more prevalent than broad ones (Fawcett \& Magnan 2002:344-345), and firms typically first pursue internal SCI, before integrating with suppliers, and finally customers (Childerhouse \& Towill 2011:7443-7444). These findings confirm those of Bernon et al. (2011:495-498) and Bernon et al. (2013:597-601), in that the first two phases of the product returns process were susceptible to performance improvements by SCI initiatives and targeted accordingly.

Thirdly, the study explored the benefits that both internal and external SCI can hold for retailers. The findings in this area mostly confirm and expand on those identified by Bernon et al. (2013: 597-602). All the benefits they attributed to internal SCI are identified within the context of this study. For external SCI, only the improved visibility of costs related to product returns is not identified. The study expands on these findings by identifying additional benefits attributed to both internal and external SCI within the context of the study. The study finds that internal SCI also leads to improved levels of customer service, process adherence and reduced levels of returns received from end customers. The study finds that external SCI leads to improved communication and information sharing, process alignment and lower levels of product returns to suppliers and subsequent costs. These benefits all generalise previous findings regarding SCI benefits within the literature to the context of the study. A novel finding within this context is the ability of external SCI to expedite the product returns process for customers in specific cases. Here, practices such as dedicated contact personnel and regular meetings enabled retailers to speed up the returns process to meet commitments to customers. 
Finally, the study sought to identify the barriers to both internal and external SCI in this context. The findings of this study confirm and add to those of Bernon et al. (2013: 597602), who focused on three barriers to external SCI, namely insufficient IT integration, SC power imbalances and reluctance to share sensitive information. Each of these barriers is identified within the context of this study. This study expands on these findings by identifying additional barriers to SCI within the context of the study. In terms of internal SCI, employees resisting the changes related to SCI and not adhering to standardised procedures, and the complexity inherent to SCI are identified as major barriers. In terms of external SCI, suppliers lacking the resources and capabilities to integrate, as well the complexity related to external SCI, are identified as major barriers. Overall, the findings of this study confirm those of Bernon et al. (2013: 586-608) as accurate and generalisable to a different retail industry and location, while contributing to SCI literature by identifying new SCI enabling practices, benefits and barriers in this context.

\section{Managerial implications}

Firstly, this study shows that managers need to be cognisant of the potential to improve their product returns process by implementing both internal and external SCI initiatives, and in doing so improve both the operational and business performance of local CE retailers.

Secondly, this study identifies numerous barriers to SCI that managers must address to increase the chance of successfully implementing SCI initiatives, and the means to overcome these barriers. The study highlights the role that individual staff play in impeding internal SCI, and the resultant need for effective training and change management initiatives to ensure buy-in and compliance from employees. Managers must also be cognisant that SCI with suppliers requires a substantial investment of time and resources, and may not be appropriate if the relationship is transactional or if the supplier lacks the capability to integrate.

\section{Limitations and directions for future research}

This study presents three main limitations. Firstly, the small sample size this study used limits the generalisability of its findings to the broader CE retail industry. Future research should be conducted using more participants, in order to increase generalisability. Secondly, this research only considered the perspective of one SC partner, namely that of the retailer. Resultantly its findings only reflect a single point of view, which might be incomplete. Future research should involve other SC partners to attain more diverse perspectives. Finally, this study only considered the perspective of large firms that typically have structures, capabilities and channel power that are dissimilar to smaller firms. Future research can use perspectives from firms of different sizes in order to determine how SCI pursuit is influenced by the size of a firm.

\section{Acknowledgements Competing interests}

The authors declare that they have no financial or personal relationships that may have inappropriately influenced them in writing this article.

\section{Authors' contributions}

This article is based on the MPhil dissertation of W.M. W.N. assisted as a supervisor with the conceptualisation, literature review, research instrument and review of the draft manuscript. T.K. provided methodological guidance.

\section{References}

Aitken, J. \& Harrison, A., 2013, 'Supply governance structures for reverse logistics systems', International Journal of Operations and Production Management 33(6) 745-764. https://doi.org/10.1108/IJOPM-10-2011-0362

Adaileh, M. \& Abu-alganam, K., 2010, 'The role of ERP in supply chain integration', International Journal of Computer Science and Network Security 10(5), 274-279.

Afshan, N., 2013, 'The performance outcomes of dimensions of supply chain integration: A conceptual framework', Business: Theory and Practice 14(4), 323-331. https://doi.org/10.3846/btp.2013.34

Alfalla-Luque, R., Medina-Lopez, C. \& Dey, P.K., 2013, 'Supply chain integration framework using literature review', Production Planning \& Control 24(8-9), 800-817.

Autry, C.W., Rose, W.J. \& Bell, J.E., 2014, 'Reconsidering the supply chain integration - Performance relationship: In search of theoretical consistency and clarity', Journal of Business Logistics 35(3), 275-276. https://doi.org/10.1111/jbl.12059

Badenhorst, A., 2016, 'Prioritising the implementation of practices to overcome operational barriers in reverse logistics: Original research', Journal of Transport and Supply Chain Management 10(1), 1-12. https://doi.org/10.4102/jtscm.v10i1.240

Badenhorst, A. \& Nel, J., 2012, 'Identifying potential solutions for specific reverse logistics problems', Journal of Transport and Supply Chain Management 6(1), 73-90. https://doi.org/10.4102/jtscm.v6i1.32

Bagchi, P.K. \& Skjoett-Larsen, T., 2003, 'Integration of information technology and organizations in a supply chain', The International Journal of Logistics Management 14(1), 89-108. https://doi.org/10.1108/09574090310806477

Bakker, F., Boehme, T. \& Van Donk, D., 2012, 'Identifying barriers to internal supply chain integration using Systems Thinking', 4th Production and Operations Management World Conference, Amsterdam, October 4-6, 2012, pp. 1-10.

Barloworld Logistics, 2013, Integrated report 2013: 9-15, viewed 3 March 2017, from https://www.barloworld.com/pdf/investors/integrated_reports/2013/booklet.pdf

Barloworld Logistics, 2014, Integrated report 2014: 11-20, viewed 3 March 2017, from https://www.barloworld.com/pdf/investors/integrated_reports/2014/booklet.pdf

Basnet, C., 2013, 'The measurement of internal supply chain integration', Management Research Review 36(2), 153-172. https://doi.org/10.1108/01409171311292252

Bernon, M. \& Cullen, J., 2007, 'An integrated approach to managing reverse logistics', International Journal of Logistics: Research and Applications 10(1), 41-56. https:// doi.org/10.1080/13675560600717763

Bernon, M., Rossi, S. \& Cullen, J., 2011, 'Retail reverse logistics: A call and grounding framework for research', International Journal of Physical Distribution \& Logistics Management 41(5), 484-510. https://doi.org/10.1108/09600031111138835

Bernon, M., Upperton, J., Bastl, M. \& Cullen, J., 2013, 'An exploration of supply chain integration in the retail product returns process', International Journal of Physical Distribution \& Logistics Management 43(7), 586-608. https://doi.org/10.1108/ IJPDLM-03-2012-0060

Bowen, G.A., 2008, 'Naturalistic inquiry and the saturation concept: A research note', Qualitative Research 8, 137-152. https://doi.org/10.1177/1468794107085301

Braun, V. \& Clarke, V., 2012, 'Thematic analysis', in H. Cooper (ed.), APA handbook of research methods in psychology: Volume 2 Research designs, American Psychological Association, Washington, DC.

Chang, W., Ellinger, A.E., Kim, K. \& Franke, G.R., 2015, 'Supply chain integration and firm financial performance: A meta-analysis of positional advantage mediation and moderating factors', European Management Journal 34, 282-295. https:// and moderating factors', European
doi.org/10.1016/j.emj.2015.11.008

Childerhouse, P. \& Towill, D.R., 2011, 'Arcs of supply chain integration', International Journal of Production Research 49(24), 7441-7468.

Creswell, J.W., 2012, Educational research: Planning, conducting, and evaluating quantitative and qualitative research, 4th edn., Pearson, Boston, MA.

Creswell, J.W., 2007, Qualitative inquiry and research design: Choosing among five approaches, 2nd edn., Sage, Thousand Oaks, CA.

Council of Supply Chain Management Professionals, 2013, Supply chain management terms and glossary, viewed 13 May 2016, from https://cscmp.org/sites/default/files/user
uploads/resources/downloads/glossary-2013.pdf?utm_source=cscmpsite\&utm_ medium=clicklinks\&utm_content=glossary\&utm_campaign=GlossaryPDF 
Dey, P.K. \& Cheffi, W., 2013, 'Managing supply chain integration: Contemporary approaches and scope for further research', Production Planning \& Control 24(8-9), 653-657.

Ellinger, A.E., Keller, S.B. \& Hansen, J.D., 2006, 'Bridging the divide between logistics and marketing: Facilitating collaborative behavior', Journal of Business Logistics 27(2), 1-27. https://doi.org/10.1002/j.2158-1592.2006.tb00215.x

EPA, 2016, Electrical and Electronic Equipment (CE), viewed 10 October 2016, from http://www.epa.ie/enforcement/wCE/electricalandelectronicequipment/

Fawcett, S.E. \& Magnan, G.M., 2002, 'The rhetoric and reality of supply chain integration', International Journal of Physical Distribution \& Logistics Management 32(5), 339-361. https://doi.org/10.1108/09600030210436222

Fawcett, S.E., Magnan, G.M. \& McCarter, M.W., 2008, 'Benefits, barriers, and bridges to effective supply chain management', Supply Chain Management: An International Journal 13(1), 35-48.

Fleischmann, M., Bloemhof-Ruwaard, J.M., Dekker, R., Van der Laan, E., Van Nunen J.A. \& Van Wassenhove, L.N., 1997, 'Quantitative models for reverse logistics: A review', European Journal of Operational Research 103(1), 1-17. https://doi org/10.1016/S0377-2217(97)00230-0

Flynn, B.B., Huo, B. \& Zhao, X., 2010, 'The impact of supply chain integration on performance: A contingency and configuration approach', Journal of Operation Management 28(1), 58-71. https://doi.org/10.1016/j.jom.2009.06.001

Flynn, B.B., Koufteros, X. \& Lu, G., 2016, 'On theory in supply chain uncertainty and its implications for supply chain integration', Journal of Supply Chain Management implications for supply chain integration', Journa
52(3), 3-27. https://doi.org/10.1111/jscm.12106

Foscht, T., Ernstreiter, K., Maloles, C., Sinha, I. \& Swoboda, B., 2013, 'Retaining or returning? Some insights for a better understanding of return behaviour', International Journal of Retail \& Distribution Management 41(2), 113-134. International Journal of Retail \& Distribution
https://doi.org/10.1108/09590551311304310

Francis, J.J., Johnston, M., Robertson, C., Glidewell, L., Entwistle, V., Eccles, M.P., et al., 2010, 'What is an adequate sample size? Operationalising data saturation for theory-based interview studies', Psychology and Health 25(10), 1229-1245. theory-based interview studies', Psychology
https://doi.org/10.1080/08870440903194015

Frohlich, M.T. \& Westbrook, R., 2001, 'Arcs of integration: An international study of supply chain strategies', Journal of Operations Management 19(2), 185-200. https://doi.org/10.1016/S0272-6963(00)00055-3

Fugate, B., Sahin, F. \& Mentzer, J.T., 2006, 'Supply chain management coordination mechanisms', Journal of Business Logistics 27(2), 129-161. https://doi.org/ 10.1002/j.2158-1592.2006.tb00220.x

Fynes, B., De Búrca, S. \& Voss, C., 2005, 'Supply chain relationship quality, the competitive environment and performance', International Journal of Production Research 43(16), 3303-3320. https://doi.org/10.1080/00207540500095894

Genchev, S.E., Richey, R.G. \& Gabler, C.B., 2011, 'Evaluating reverse logistics programs: A suggested process formalization', The International Journal of Logistic Management 22(2), 242-263. https://doi.org/10.1108/09574091111156578

Georgise, F.B., Thoben, K.-D. \& Seifert, M., 2014, 'Supply chain integration in the manufacturing firms in developing country: An Ethiopian case study', Journal of Industrial Engineering 2014, 1-13. https://doi.org/10.1155/2014/251982

Gil-Garcia, J.R., Chengalur-Smith, I. \& Duchessi, P., 2007, 'Collaborative e-Government: Impediments and benefits of information-sharing projects in the public sector', European Journal of Information Systems 16(2), 121-133. https://doi.org/ 10.1057/palgrave.ejis.3000673

Guide, V.D.R. \& Van Wassenhove, L.N., 2009, 'The evolution of closed-loop supply chain research', Operations Research 57(1), 10-18. https://doi.org/10.1287/ opre.1080.0628

Heyns, G. \& Luke, R., 2012, 'Skills requirements in the supply chain industry in South Africa', Journal of Transport and Supply Chain Management 6(1), 107-125. https://doi.org/10.4102/jtscm.v6i1.34

Huang, M.-C., Yen, G.-F. \& Liu, T.-C., 2014, 'Reexamining supply chain integration and the supplier's performance relationships under uncertainty', Supply Chain Management: An International Journal 19(1), 64-78.

Huscroft, J., Hazen, B., Hall, D., Skipper, J. \& Hanna, J., 2013, 'Reverse logistics: Past research, current management issues, and future directions', The International Journal of Logistics Management 24(3), 304-327. https://doi.org/10.1108/IJLM04-2012-0024

IMF, 2016, World economic outlook: Too slow for too long, viewed 13 May 2016, from https://www.imf.org/external/pubs/ft/weo/2016/01/pdf/text.pdf

Jack, E.P., Powers, T.L. \& Skinner, L., 2010, 'Reverse logistics capabilities: Antecedent and cost savings', International Journal of Physical Distribution \& Logistic Management 40(3), 228-246. https://doi.org/10.1108/09600031011035100

Janse, B., Schuur, P. \& De Brito, M.P., 2010, 'A reverse logistics diagnostic tool: The case of the consumer electronics industry', The International Journal of Advanced Manufacturing Technology 47(5), 495-513. https://doi.org/10.1007/s00170-009 2333-z

Jayaraman, V., Ross, A.D. \& Agarwal, A., 2008, 'Role of information technology and collaboration in reverse logistics supply chains', International Journal of Logistics: Research and Applications 11(6), 409-425. https://doi.org/10.1080/1367556 0701694499

Jin, Y., Fawcett, A.M. \& Fawcett, S.E., 2013, 'Awareness is not enough: Commitment and performance implications of supply chain integration', International Journal of Physical Distribution \& Logistics Management 43(3), 205-230. https://doi org/10.1108/IJPDLM-10-2011-0169

Kamal, M.M. \& Irani, Z., 2014, 'Analysing supply chain integration through a systematic literature review: A normative perspective', Supply Chain Management: An International Journal 19(5/6), 523-557.
Kannan, V.R. \& Tan, K.C., 2010, 'Supply chain integration: Cluster analysis of the impact of span of integration', Supply Chain Management: An International Journal 15(3), 207-215.

Khurana, M., Mishra, P. \& Singh, A., 2011, 'Barriers to information sharing in supply chain of manufacturing industries', International Journal of Manufacturing Systems 1(1), 9-29. https://doi.org/10.3923/ijmsaj.2011.9.29

Kim, D.Y., 2013, 'Relationship between supply chain integration and performance', Operations Management Research 6(1), 74-90. https://doi.org/10.1007/s12063013-0079-0

Koufteros, X.A., Edwin Cheng, T.C. \& Lai, K.H., 2007, "'Black-box" and "gray-box" supplier integration in product development: Antecedents, consequences and the moderating role of firm size', Journal of Operations Management 25(4), 847-870. https://doi.org/10.1016/j.jom.2006.10.009

Koufteros, X.A., Rawski, G.E. \& Rupak, R., 2010, 'Organizational integration for product development: The effects on glitches, on-time execution of engineering change orders, and market success', Decision Sciences 41(1), 49-80. https://doi.org/ 10.1111/j.1540-5915.2009.00259.x

KPMG, 2014, 10th Annual state of logistics survey - Bold steps forward, viewed 12 March 2013, from http://www.kpmg.com/ZA/en/IssuesAndlnsights/ArticlesPublications/ Management-Consulting/Documents/10th_SoL_Bold_Steps_Forward_web.pdf

Li, S. \& Lin, B., 2006, 'Accessing information sharing and information quality in supply chain management', Decision Support Systems 42(3), 1641-1656. https://doi. chain management', Decision
org/10.1016/j.dss.2006.02.011

Li, G., Yang, H., Sun, L. \& Sohal, A.S., 2009, 'The impact of IT implementation on supply chain integration and performance', International Journal of Production Economics, 120(1), 125-138. https://doi.org/10.1016/j.ijpe.2008.07.017

Leuschner, R., Rogers, D.S. \& Charvet, F.F., 2013, 'A meta-analysis of supply chain integration and firm performance', Journal of Supply Chain Management 49(2), 34-57. https://doi.org/10.1111/jscm.12013

Mackelprang, A.W., Robinson, J.L., Bernardes, E. \& Webb, G.S., 2014, 'The relationship between strategic supply chain integration and performance: A meta-analytic evaluation and implications for supply chain management research', Journal of Business Logistics 35(1), 71-96. https://doi.org/10.1111/jbl.12023

Mai, E.S., Chen, H. \& Anselmi, K., 2012, 'The role of returns management orientation, internal collaboration, and information support in reverse logistics', Journal of Transportation Management 23(1), 45-59.

Manuj, I. \& Sahin, F., 2011, 'A model of supply chain and supply chain decision-making complexity', International Journal of Physical Distribution \& Logistics Management complexity', International Journal of Physical Distribution \& Logistic
41(5), 511-549. https://doi.org/10.1108/09600031111138844

Narasimhan, R. \& Kim, S.W., 2002, 'Effect of supply chain integration on the relationship between diversification and performance: Evidence from Japanese and Korean firms', Journal of Operations Management 20(3), 303-323. https:// doi.org/10.1016/S0272-6963(02)00008-6

Narasimhan, R., Swink, M. \& Viswanathan, S., 2010, 'On decisions for integration implementation: An examination of complementarities between product-process technology integration and supply chain integration', Decision Sciences 41(2), 355-372. https://doi.org/10.1111/j.1540-5915.2010.00267.x

OECD, 2015, South Africa - Economic forecast summary (November 2015), viewed 13 May 2016, from https://www.oecd.org/economy/south-africa-economicforecast-summary.htm

Olariu, I., 2014, 'An overview on retail reverse logistics', Studies and Scientific Researches. Economics edition 2014(19), 189-195.

Olorunniwo, F.O. \& Li, X., 2010, 'Information sharing and collaboration practices in reverse logistics', Supply Chain Management: An International Journal 15(6), 454-462.

Pagell, M., 2004, 'Understanding the factors that enable and inhibit the integration of operations, purchasing and logistics', Journal of Operations Management 22(5), 459-487. https://doi.org/10.1016/j.jom.2004.05.008

Percy, W.H., Kostere, K. \& Kostere, S., 2015, 'Generic qualitative research in psychology', The Qualitative Report 20(2), 76-85.

Pérez-Belis, V., Bovea, M. \& Ibáñez-Forés, V., 2015, 'An in-depth literature review of the waste electrical and electronic equipment context: Trends and evolution', Waste Management \& Research 33(1), 3-29. https://doi.org/10.1177/07342 $42 \times 14557382$

Plano Clark, V.L. \& Creswell, J.W., 2015, Understanding research: A consumer's guide, 2nd edn., Pearson, Upper Saddle River, NJ.

Polit, D.F. \& Beck, C.T., 2012, Nursing research: Generating and assessing evidence for nursing practise, 9th edn., Lippincott Williams \& Wilkins, Philadelphia, PA.

Powers, T.L. \& Jack, E.P., 2015, 'Understanding the causes of retail product returns', International Journal of Retail \& Distribution Management 43(12), 1182-1202. https://doi.org/10.1108/IJRDM-02-2014-0023

Prajogo, D. \& Olhager, J., 2012, 'Supply chain integration and performance: The effects of long-term relationships, information technology and sharing, and logistics integration', International Journal of Production Economics 135(1), 514-522. https://doi.org/10.1016/j.ijpe.2011.09.001

Prakash, C. \& Barua, M.K., 2015, 'Integration of AHP-TOPSIS method for prioritizing the solutions of reverse logistics adoption to overcome its barriers under fuzzy environment', Journal of Manufacturing Systems 37(3), 599-615. https://doi. org/10.1016/j.jmsy.2015.03.001

PWC, 2012, South African retail and consumer products outlook 2012-2016, viewed 10 June 2016, from https://www.pwc.co.za/en/assets/pdf/retail-and-consumerproducts-outlook-2012-2016.pdf

Quesada, G., Rachamadugu, R., Gonzalez, M. \& Martinez, J.L., 2008, 'Linking order winning and external supply chain integration strategies', Supply Chain Management: An International Journal 13(4), 296-303. https://doi.org/10.1108/13598540810882189 
Rai, A., Patnayakuni, R. \& Seth, N., 2006, 'Firm performance impacts of digitally enabled supply chain integration capabilities', MIS Quarterly 30(2), 225-246.

Rajagopal, P., Kaliani Sundram, V.P. \& Naidu, B.M., 2015, 'Future directions of reverse logistics in gaining competitive advantages. A review of literature', International Journal of Supply Chain Management 4(1), 39-48.

Ralston, P.M., Blackhurst, J., Cantor, D.E. \& Crum, M.R., 2015, 'A structure - Conduct - Performance perspective of how strategic supply chain integration affects firm performance', Journal of Supply Chain Management 51(2), 47-64. https://doi. org/10.1111/jscm.12064

Reverse Logistics Association, 2009, What is reverse logistics? viewed 10 June 2016 from https://www.reverselogisticstrends.com/reverse-logistics.php

Richey, R.G., Chen, H., Upreti, R., Fawcett, S.E. \& Adams, F.G., 2009, 'The moderating role of barriers on the relationship between drivers to supply chain integration and firm performance', International Journal of Physical Distribution \& Logistics Management 39(10), 826-840. https://doi.org/ 10.1108/09600030911011432

Richey, R.G., Roath, A.S., Whipple, J.M. \& Fawcett, S.E., 2010, 'Exploring a governance theory of supply chain management: Barriers and facilitators to integration' Journal of Business Logistics 31(1), 237-256. https://doi.org/10.1002/j.2158-1592. 2010.tb00137.x

Rogers, D.S., Lambert, D.M., Croxton, K.L. \& García-Dastugue, S.J., 2002, 'The returns management process', The International Journal of Logistics Management 13(2) 1-18. https://doi.org/10.1108/09574090210806397

Rogers, D.S. \& Tibben-Lembke, R.S., 1999, Going backwards: Reverse logistics trends and practices, Reverse Logistics Executive Council, Pittsburgh, PA.

Rosenzweig, E.D., Roth, A.V. \& Dean, J.W. Jr, 2003, 'The influence of an integration strategy on competitive capabilities and business performance: An exploratory study of consumer products manufacturers', Journal of Operations Management 21(4), 437-456. https://doi.org/10.1016/S0272-6963(03)00037-8

Saunders, M., Lewis, P. \& Thornhill, A., 2016, Research methods for business students, 7th edn., Pearson, Edinburgh Gate, Harlow.

Schoenherr, T. \& Swink, M., 2012, 'Revisiting the arcs of integration: Cross-validations and extensions', Journal of Operations Management 30(1-2), 99-115. https://doi. org/10.1016/j.jom.2011.09.001

Sciarrotta, T., 2003, 'How Philips reduced returns', Supply Chain Management Revision 7(6), 32-38.

Sheu, C. Yen, H.R. \& Chae, B., 2006, 'Determinants of supplier-retailer collaboration: Evidence from an international study', International Journal of Operations \& Evidence from an international study', International Journal of Operations \&
Production Management 26(1), 24-49. https://doi.org/10.1108/0144357061 0637003

Shenton, A.K., 2004, 'Strategies for ensuring trustworthiness in qualitative research projects', Education for information 22(2), 63-75. https://doi.org/10.3233/EFI2004-22201

South Africa, 2008, Consumer Protection Act, No. 68 of 2008.

Statistics South Africa, 2013, Retail trade industry, 2012: 1-25, viewed 12 May 2016 from http://www.statssa.gov.za/publications/P6201/P62012012.pdf

Statistics South Africa, 2014, Gross domestic product, 2015: 1-36, viewed 12 May 2016, from http://www.statssa.gov.za/publications/P6201/P62014011.pdf
Storey, J., Emberson, C. \& Reade, D., 2005, 'The barriers to customer responsive supply chain management', International Journal of Operations \& Production Management 25(3), 242-260. https://doi.org/10.1108/01443570510581853

Stevens, G.C. \& Johnson, M., 2016, 'Integrating the supply chain ... 25 years on', International Journal of Physical Distribution \& Logistics Management 46(1), 19-42. https://doi.org/10.1108/IJPDLM-07-2015-0175

Stock, J.R., Boyer, S.L. \& Harmon, T., 2010, 'Research opportunities in supply chain management', Journal of the Academy of Marketing Science 38(1), 32-41. https:// doi.org/10.1007/s11747-009-0136-2

Stock, J.R. \& Mulki, J.P., 2009, 'Product returns processing: An examination of practices of manufacturers, wholesalers/distributors, and retailers', Journal of Business Logistics 30(1), 33-62. https://doi.org/10.1002/j.2158-1592.2009.tb00098.x

Srivastava, S.K., 2013, 'Issues and challenges in reverse logistics', in S.M. Gupta (ed.), Reverse supply chains - Issues and analysis, pp. 61-82, CRC-Press, Florida.

Srivastava, S.K. \& Srivastava, R.K., 2006, 'Managing product returns for reverse logistics' International Journal of Physical Distribution \& Logistics Management 36(7), 524-546. https://doi.org/10.1108/09600030610684962

Swink, M., Narasimhan, R. \& Wang, C., 2007, 'Managing beyond the factory walls: Effects of four types of strategic integration on manufacturing plant performance Journal of Operations Management 25(1), 148-164. https://doi.org/10.1016/j. jom.2006.02.006

Thomas, E. \& Magilvy, J.K., 2011, 'Qualitative rigor or research validity in qualitative research', Journal for Specialists in Pediatric Nursing 16(2), 151-155. https://doi. org/10.1111/j.1744-6155.2011.00283.x

Tibben-Lembke, R.S. \& Rogers, D.S., 2002. 'Differences between forward and reverse logistics in a retail environment', Supply Chain Management: An Internationa Journal 7(5), 271-282.

Van der Vaart, T. \& Van Donk, D.P., 2008, 'A critical review of survey-based research in supply chain integration', International Journal of Production Economics 111(1) 42-55. https://doi.org/10.1016/j.ijpe.2006.10.011

Vickery, S.K., Jayaram, J., Droge, C. \& Calantone, R., 2003, 'The effects of an integrative supply chain strategy on customer service and financial performance: An analysis of direct versus indirect relationships', Journal of Operations Management 21(5) 523-539. https://doi.org/10.1016/j.jom.2003.02.002

WESGRO, 2013, Consumer Electronics, viewed 13 May 2016, from http://wesgro.co. $\mathrm{za} /$ publications/publication/2014-western-cape-consumer-electronics-sector

Wee Kwan Tan, A. \& Kumar, A., 2006, 'A decision-making model for reverse logistics in the computer industry', The International Journal of Logistics Management 17(3), 331-354. https://doi.org/10.1108/09574090610717518

Wong, C.Y., Boon-Itt, S. \& Wong, C.W., 2011, 'The contingency effects of environmental uncertainty on the relationship between supply chain integration and operational performance', Journal of Operations Management 29(6), 604-615. https://doi. org/10.1016/j.jom.2011.01.003

Williams, B.D., Roh, J., Tokar, T. \& Swink, M., 2013, 'Leveraging supply chain visibility for responsiveness: The moderating role of internal integration', Journal of Operation Management 31(7-8), 543-554. https://doi.org/10.1016/j.jom.2013.09.003

Zhao, X., Huo, B., Selen, W. \& Yeung, J.H.Y., 2011, 'The impact of internal integration and relationship commitment on external integration', Journal of Operations Management 29(1-2), 17-32. https://doi.org/10.1016/j.jom.2010.04.004 